\title{
Syntheses of prodelphinidin B3 and C2, and their antitumor activities through cell cycle arrest and caspase- 3 activation
}

\author{
Wataru Fujii, ${ }^{a}$ Kazuya Toda, ${ }^{\mathrm{b}}$ Koichiro Kawaguchi, ${ }^{\mathrm{b}}$ Sei-ichi Kawahara, ${ }^{\mathrm{c}}$ Miyuki Katoh, ${ }^{\mathrm{a}}$ Yasunao \\ Hattori, ${ }^{\mathrm{d}}$ Hiroshi Fujii*, ${ }^{\mathrm{b}}$ and Hidefumi Makabe*a
}

${ }^{\mathrm{a}}$ Graduate School of Agriculture, Sciences of Functional Foods, Shinshu University,

8304 Minami-minowa Kami-ina, Nagano, 399-4598, Japan

${ }^{\mathrm{b} D e p a r t m e n t}$ of Bioscience and Biotechnology, Faculty of Agriculture, Shinshu University, 8304 Minami-minowa Kami-ina, Nagano, 399-4598, Japan

${ }^{c}$ St. Cousair Co., Ltd., 1260 Imogawa, Kamiminochi, Nagano, 389-1201, Japan

${ }^{\mathrm{d}}$ Department of Medicinal Chemistry, Kyoto Pharmaceutical University, Yamashina-ku, Kyoto 607-8412, Japan

\begin{abstract}
*Corresponding author. Tel. +81 26577 1629; fax +81 26577 1629; e-mail: hfujii @ shinshu-u.ac.jp
*Corresponding author. Tel. +81 26577 1630; fax +81 26577 1700; e-mail: makabeh@shinshu-u.ac.jp
\end{abstract}

\begin{abstract}
Total synthesis of prodelphinidin B3 and C2 have been accomplished. The key step is Lewis acidmediated equimolar condensations between a catechin and/or gallocatechin nucleophile and a gallocatechin electrophile. The antitumor effects of synthetic prodelphidin B3 and C2 against PC-3 prostate cancer cell lines have been investigated. Both compounds showed significant antitumor effects. Their activity was almost the same as that of EGCG, a known antitumor agent.
\end{abstract}

Key words: polyphenols, synthesis, natural product, anticancer agents

\section{Introduction}

Recently proanthocyanidins have been receiving much attention due to their significant bioactivities. ${ }^{1,2}$ However, because identification and purification from nature are extremely difficult, the mechanism for their biological activities remains unsolved. Thus, researchers have sought to synthesize proanthocyanidins. ${ }^{3-5}$ Syntheses of procyanidins (oligomeric catechin and/or epicatechin) have been reported in the past decade for the end goal of obtaining proanthocyanidins in a pure state. ${ }^{6-28}$ However synthetic studies on prodelphinidins which 
contains (-)-gallocatechin or (+)-epigallocatechin are quite limited. ${ }^{29}$ Until now no total synthesis of prodelphinidins has been reported. The typical synthesis of catechin derived oligomers can be accomplished using Lewis acid-mediated condensation of catechin nucleophiles and electrophiles. The disadvantage of this reaction is that using an excess amount of nucleophile is necessary to avoid polymerization. Recently, we have developed an efficient synthesis of procyanidins through equimolar condensation of catechin nucleophiles with electrophiles. The typical examples are as follows: 1) For synthesis of a catechin dimer, we accomplished equimolar coupling between nucleophilic and electrophilic partners for the first time using $\mathrm{Yb}(\mathrm{OTf})_{3}$ as a Lewis acid. $^{7,9,10,13}$ 2) For synthesis of a catechin trimer, equimolar coupling between a nucleophilic catechin dimer and monomeric electrophilic partner ( $2+1$ coupling) was accomplished using silver Lewis acids such as $\mathrm{AgBF}_{4}$ or AgOTf. ${ }^{22,30}$ Herein we demonstrate equimolar condensation of a catechin and/or a gallocatechin nucleophile with a gallocatechin-derived electrophile and the first total synthesis of prodelphinidin B3 (PDB3, 1) and C2 (PDC2, 2) (Figure 1).
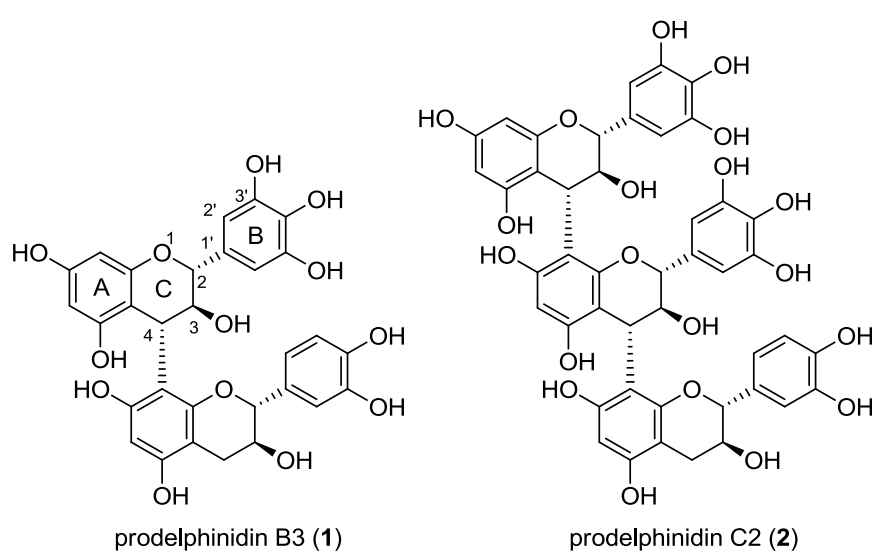

Figure 1. The structures of prodelphinidin B3 (1) and C2 (2).

\section{Results and discussion}

\subsection{Synthesis}

The gallocatechin-derived building block 5 was constructed as Chan and co-workers reported with slight modification. ${ }^{31}$ DDQ oxidation in the presence of methanol or ethoxyethanol gave electrophiles 6 and 7, respectively (Scheme 1).

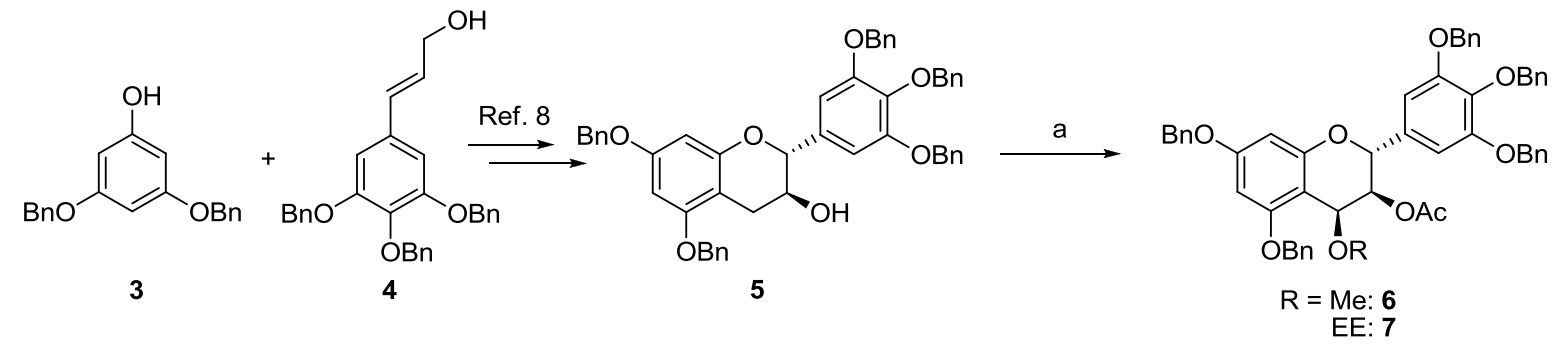

Scheme 1. Synthesis of gallocatechin electrophiles 6 and 7.

Reagents and conditions: (a) (i) DDQ, ROH; (ii) $\mathrm{Ac}_{2} \mathrm{O}$, pyridine, DMAP, $37 \%$ for $\mathbf{6}, 51 \%$ for 7. 
Since the gallocatechin electrophile $\mathbf{6}$ and $\mathbf{7}$ were in hand, we examined the condition of equimolar condensation of catechin nucleophile 8 with gallocatechin electrophile 6 or 7. As shown in Table 1, 4-(2"-ethoxyethoxy) derivative 7 afforded condensed product in high yield when $\mathrm{Yb}(\mathrm{OTf})_{3}$ was used as Lewis acid. To our surprise, the reaction using methoxy derivative $\mathbf{6}$ gave $\mathbf{9}$ in very poor yield although nucleophile $\mathbf{8}$ with a related electrophile, the yield was $64 \%$ as we have reported earlier. ${ }^{13}$ We confirmed that the leaving the group at the C4 position was crucial in the $\mathrm{Yb}(\mathrm{OTf})_{3}$ mediated condensation (Table 1). ${ }^{9}$

Table 1. Equimolar condensation of gallocatechin electrophile 6 or 7 with catechin nucleophile 8 . $^{\text {a }}$

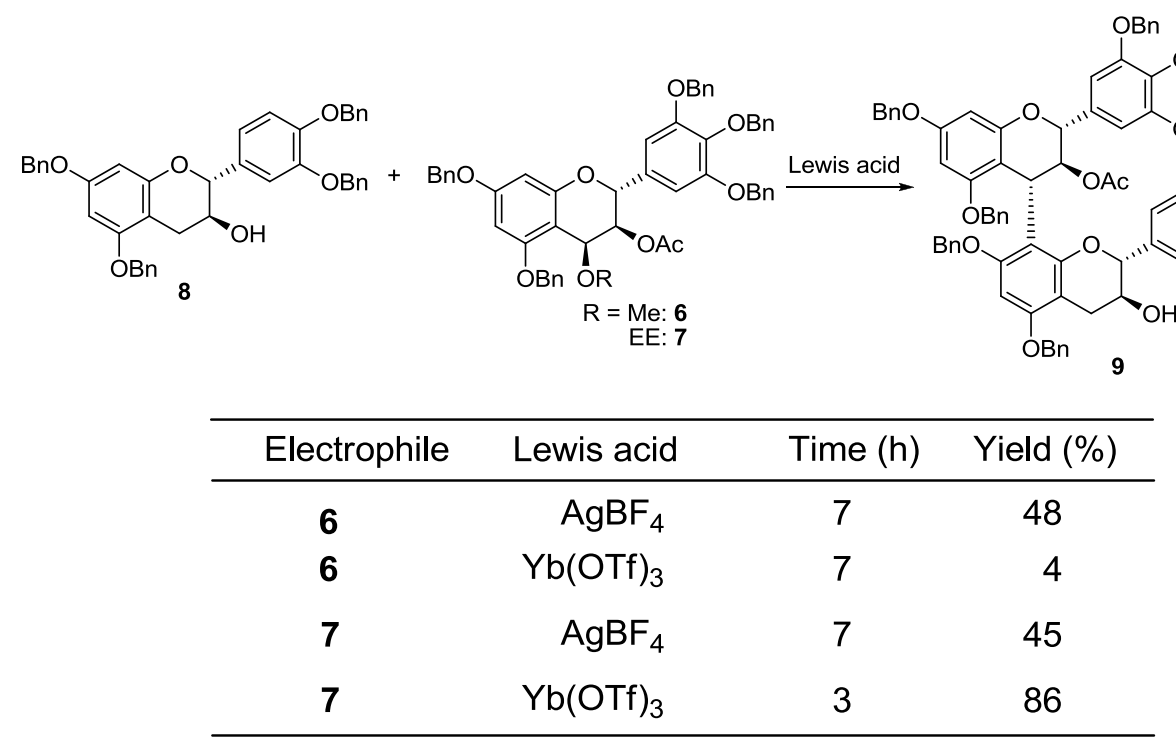

aThe reaction was carried out in $\mathrm{CH}_{2} \mathrm{Cl}_{2}$ at room temperature.

The condensed product 9 was transformed into diol 10 using $n-\mathrm{Bu}_{4} \mathrm{NOH} .{ }^{28}$ The ${ }^{1} \mathrm{H}$ and ${ }^{13} \mathrm{C}$ NMR spectral data of 10 were in good agreement with the reported values. ${ }^{29}$ The 3,4-cis diastereomer was not detected. Finally deprotection of the benzyl ethers of $\mathbf{1 0}$ and subsequent lyophilization afforded prodelphinidin B3 (1) in good yield. The ${ }^{1} \mathrm{H}$ spectral data of peracetate of 1 (11) were in good agreement with the reported values (Scheme 2). 32,33

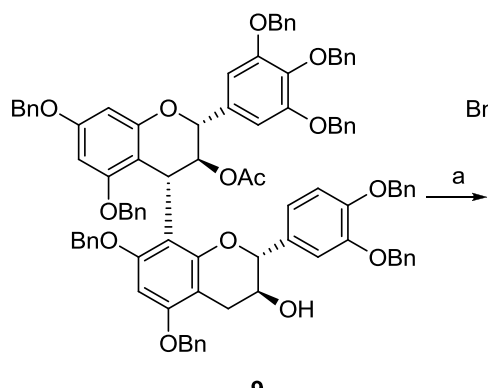

9

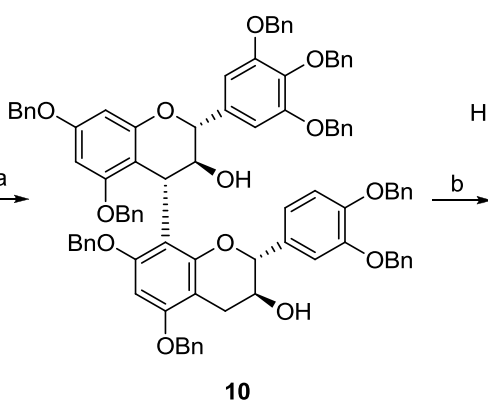

10

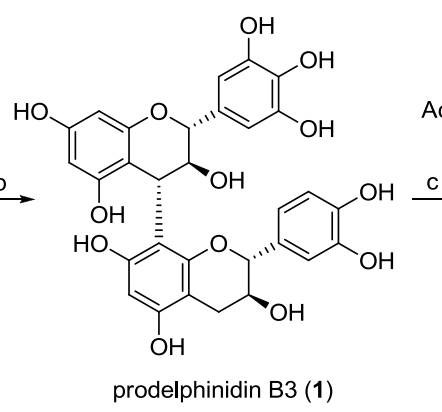

prodelphinidin B3 (1)

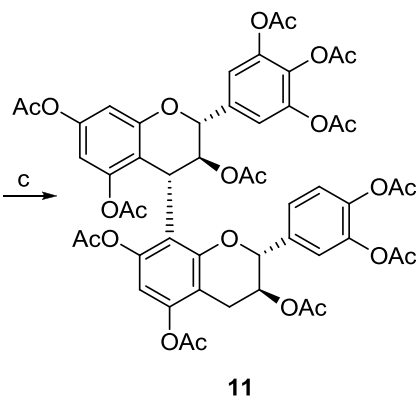

11

Scheme 2. Synthesis of prodelphinidin B3 (1) and its peracetate 11.

Reagents and conditions:(a) $n$ - $\mathrm{Bu}_{4} \mathrm{NOH}, 82 \%$; (b) $\mathrm{H}_{2}, \mathrm{Pd}(\mathrm{OH})_{2} / \mathrm{C}, 96 \%$; (c) $\mathrm{Ac}_{2} \mathrm{O}$, pyridine, DMAP, $28 \%$.

Because diol 10 could be used as a nucleophile for the synthesis of prodelphinidin C2 (2), we focused on the 
equimolar condensation of $\mathbf{1 0}$ with electrophile $\mathbf{6}$ or 7. In the previous report, we found that silver Lewis acids were effective for the construction of catechin trimer derivatives. ${ }^{22,30}$ Thus we used $\mathrm{AgBF}_{4}$ and $\mathrm{AgOTf}_{\text {as Lewis }}$ acid. As shown in Table 2, the 4-methoxy derivative $\mathbf{6}$ afforded condensed product 12 in good yield when AgOTf was used as a Lewis acid. The reaction using $\mathrm{AgBF}_{4}$ as Lewis acid and 4-methoxy derivative $\mathbf{6}$ as an electrophile afforded 12 in poor yield although electrophile 6 with a related nucleophile, the yield was $85 \%$ as we have reported earlier. ${ }^{30} \mathrm{We}$ found the combination of the $\mathrm{C} 4$ leaving group and silver Lewis acid was very important (Table 2).

Table 2. Condensation of gallocatechin electrophile $\mathbf{6}$ or $\mathbf{7}$ with nucleophile 10. ${ }^{\mathrm{a}}$

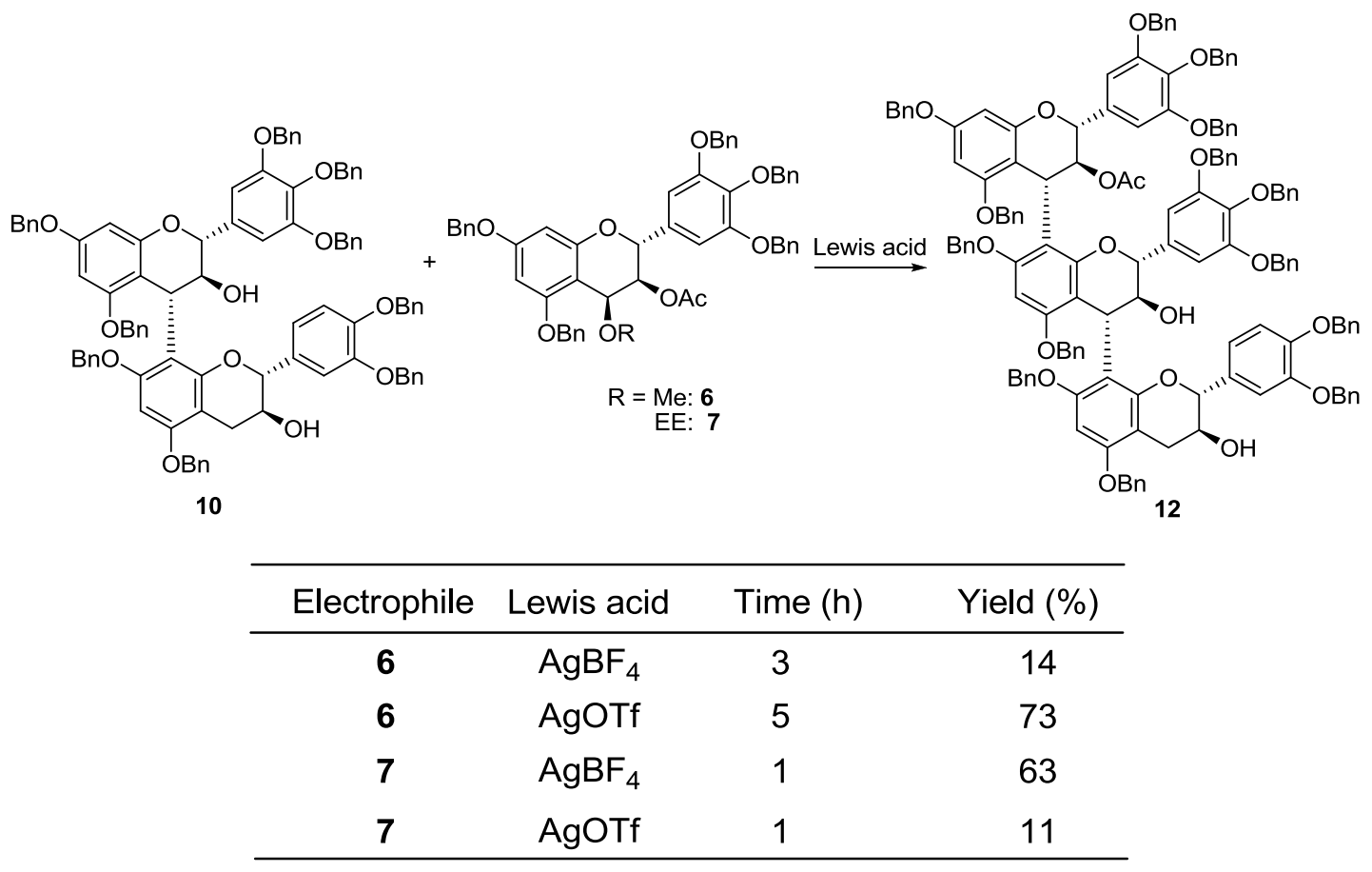

aThe reaction was carried out in $\mathrm{CH}_{2} \mathrm{Cl}_{2}$ at room temperature.

The condensed product 12 was transformed into triol 13 using $n-\mathrm{Bu}_{4} \mathrm{NOH} .{ }^{28}$ Finally deprotection of the benzyl ethers of 13 and subsequent lyophilization afforded prodelphinidin C2 (2) in good yield. We confirmed that lyophilized prodelphinidin C2 (2) was pure (>95\%) by HPLC analysis. ${ }^{34}$ The ${ }^{1} \mathrm{H}$ spectral data of peracetate 14 were in good agreement with the reported values (Scheme 3). ${ }^{32,35}$ 


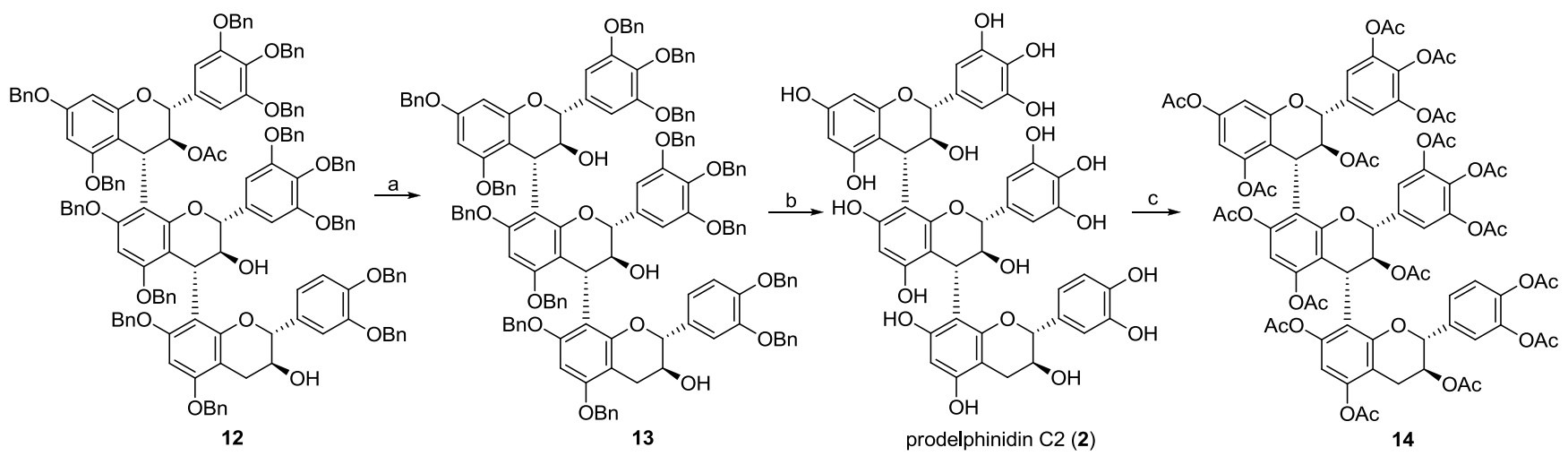

Scheme 3. Synthesis of prodelphinidin C2 (2) and its peracetate 14.

Reagents and conditions: (a) $n$ - $\mathrm{Bu}_{4} \mathrm{NOH}, 77 \%$; (b) $\mathrm{H}_{2}, \mathrm{Pd}(\mathrm{OH})_{2} / \mathrm{C}, 96 \%$; (c) $\mathrm{Ac}_{2} \mathrm{O}$, pyridine, DMAP, $27 \%$.

\subsection{Cytotoxic effects on PC-3 prostate cancer cell.}

Our interest was focused on examining the antitumor activities of the newly synthesized prodelphinidins. The synthesis of prodelphinidin B3 (1) and C2 (2) allowed us to obtain sufficient quantities of purified compounds to screen against PC-3 prostate cancer cell lines together with procyanidin B3, C1 and C2 which were prepared by us previously (Figure 2). ${ }^{9,13,22}$<smiles>O=C(O[C@H]1Cc2c(O)cc(O)cc2O[C@H]1c1cc(O)c(O)c(O)c1)c1cc(O)c(O)c(O)c1</smiles>

epigallocatechin-gallate (EGCG)

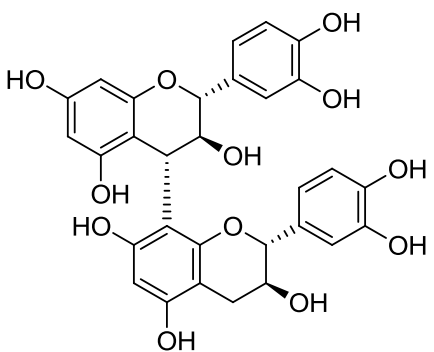

procyanidin B3 (PCB3)

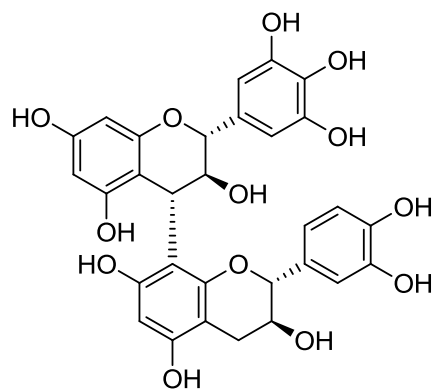

prodelphinidin B3 (PDB3,1)

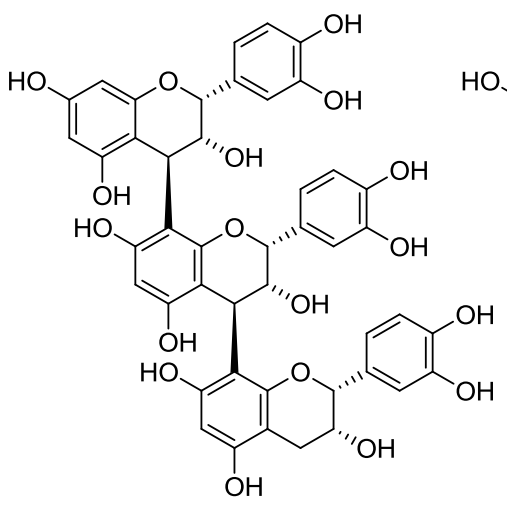

procyanidin $\mathrm{C} 1$ (PCC1)

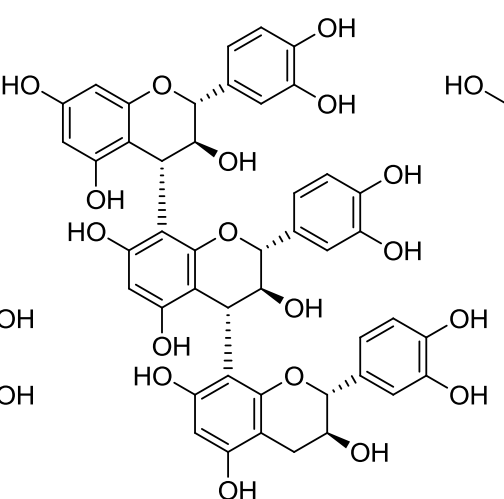

procyanidin $\mathrm{C} 2(\mathrm{PCC} 2)$

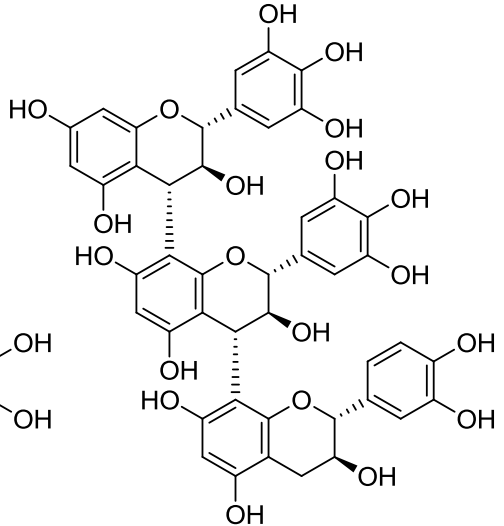

prodelphinidin C2 (PDC2, 2)

Figure 2. The structures of test compounds for PC3 prostate anticancer activity.

Results were obtained by two independent methods: cell count measurement and MTT assay. Epigallocatechin gallate (EGCG) was used as a positive control. As shown in Figure 3, EGCG, prodelphinidin B3 (1) and C2 (2) exhibited significant cytotoxic activity with $\mathrm{IC}_{50}$ values below $50 \mu \mathrm{M}$. A comparison of the potencies of $\mathbf{1}$ and 
procyanidin B3, suggested that the cytotoxic effects were clearly associated with the presence of the pyrogallol moiety of the B ring. PDB3 (1) and PCB3 have the same carbon skeleton. The only difference is that PDB3 has an additional hydroxy group at the B ring. We found that this hydroxy group greatly affected the level of the cytotoxic effect. As for $\mathbf{2}$ and procyanidin $\mathrm{C} 1$ or $\mathrm{C} 2$, the pyrogallol moiety was essential for their activity. ${ }^{36}$ Comparisons between 1 and either $\mathbf{2}$ or EGCG suggested that the number of pyrogallol moieties did not seem to affect the activity. This tendency was also observed in the MTT assay. This finding might be useful in searching for antitumor molecules among the proanthocyanidins (Figure 3).

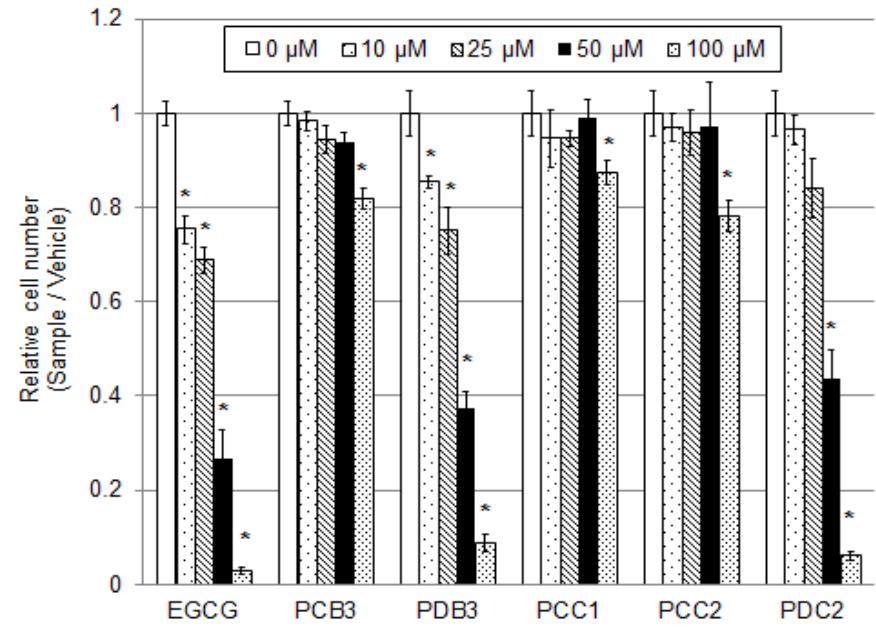

A

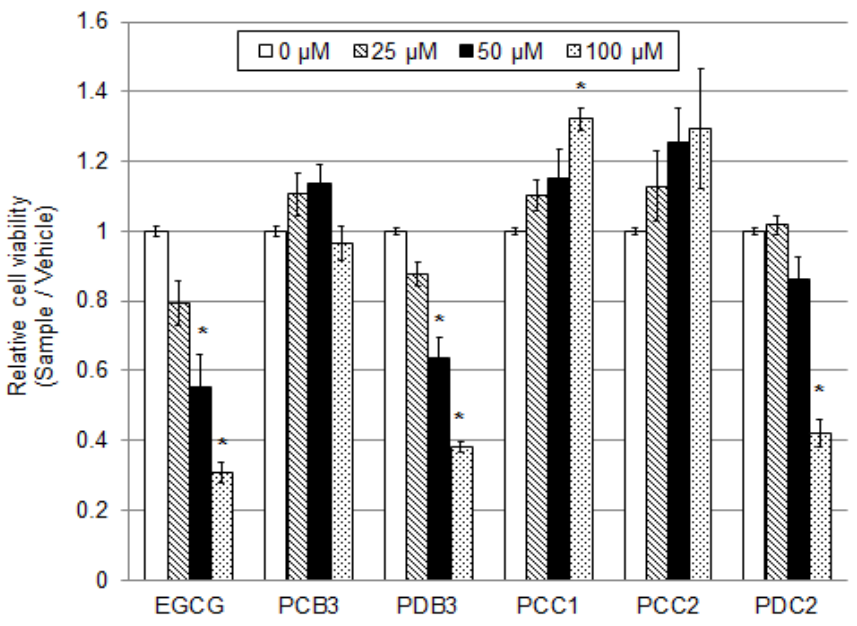

$\mathrm{B}$

Figure 3. Effects of various concentrations of test compounds on cell proliferation.

After treatment of cells with EGCG, PCB3, PCC1, PCC2, PDB3, PDC2, or CPT for $48 \mathrm{~h}$, the cell proliferation was determined by cell count (A) and MTT assay (B) as shown in supplementary data. The values were represented as the rate of inhibition of cell proliferation by the treated sample compared to the untreated control (vehicle). Values are means \pm S.Ds. for three independent experiments. Asterisks indicated a significant difference between the control- and test-compound-treated cells, as analyzed by Student's test $(\mathrm{p}<0.001)$.

\subsection{Effects on cell cycle distribution.}

Cell growth and proliferation are mediated via cell cycle progression. Loss of cell cycle control can initiate the apoptotic program. ${ }^{37}$ In the present studies, treatment of PC-3 prostate cancer cells with $50 \mu \mathrm{M}$ of prodelphinidin B3 (1) for $48 \mathrm{~h}$ induced a G1/G0 phase population increase from $62.88 \%$ to $74.50 \%$ and an $\mathrm{S}$ phase fraction decrease from $16.06 \%$ to $8.67 \%$. Obviously, prodelphinidin B3 (1) blocked the PC-3 prostate cancer cell cycle partly at the G1/G0 phase within 48h. EGCG and prodelphinidin C2 (2) showed a similar effect. On the other hand, no effect from procyanidin B3, C1 or C2 was observed. A lower S-phase population indicated a slower cell division and growing tumor. Compounds which promote cell apoptosis and inhibit proliferation of cancer cells 
are likely to be good candidates as antitumor agents. ${ }^{38}$ Our findings suggest that prodelphinidins might be promising chemopreventive agents against prostate cancer (Figure 4).

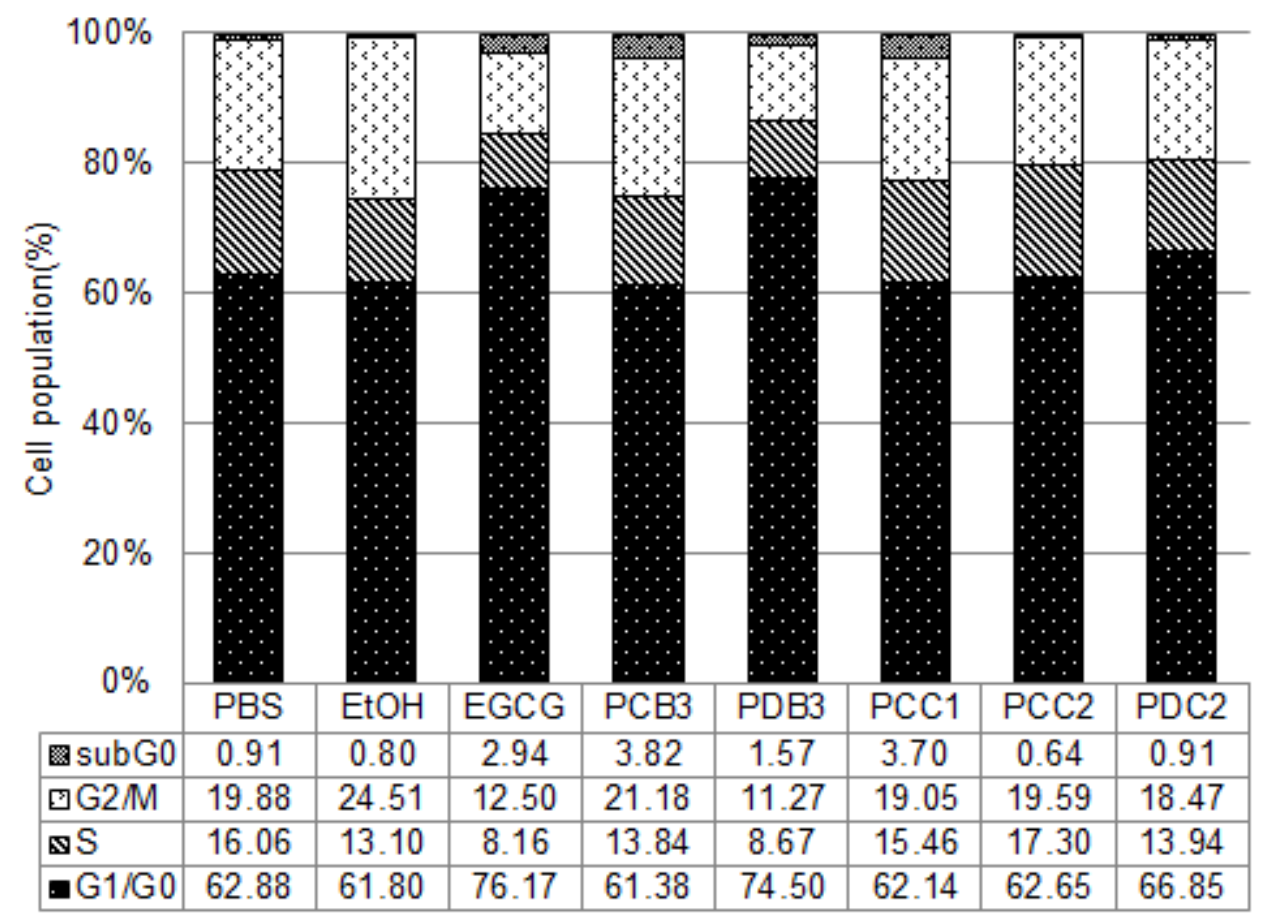

Figure 4. Effects of test compounds on cell cycle distribution.

The cells treated with test compounds (EGCG, PCB3, PDB3, PCC1, PCC2, or PDC2) for 48 h were collected and stained with propidium iodide using a BD Cycletest ${ }^{\mathrm{TM}}$ Plus DNA Reagent Kit (Becton Dickinson and Company BD Biosciences) obtained from Phoenix Flow Systems. Following FACS analysis, cell cycle distributions were further analyzed by Cell Quest software. The phase fraction (\%) is shown in the graph. The experimental data are shown in supplementary data.

\subsection{Effects on caspase-3 activity.}

It has been well known that the caspases initiate cell apoptosis caused by some stimuli. ${ }^{39}$ Caspases are synthesized as inactive proenzymes which need proteolytic cleavage for activation. Caspase-3 is related to the enforcement phase of apoptosis, where cells undergo morphological changes such as chromatin condensation, apoptotic body formation, and DNA fragmentation. ${ }^{40}$ As caspase- 3 is the most important enzyme involved in execution of apoptosis, its activation, and formation of cleaved caspase-3, is a biochemical marker of early apoptosis. Therefore, the detection of active caspase-3 in cells is a reliable method of measuring apoptosis. Thus, we next examined the caspase- 3 activity to confirm that the cells exposed to prodelphinidin were actually undergoing apoptosis, and to determine whether caspase-3 was involved in the cell death pathway. We found that EGCG, prodelphinidin B3 (1), and prodelphinidin C2 (2) activated caspase-3 up to 1.5 1.8 times compared to the control. Thus, we concluded that the cell death caused by prodelphinidins was attributable to a kind of apoptosis (Figure 5). 


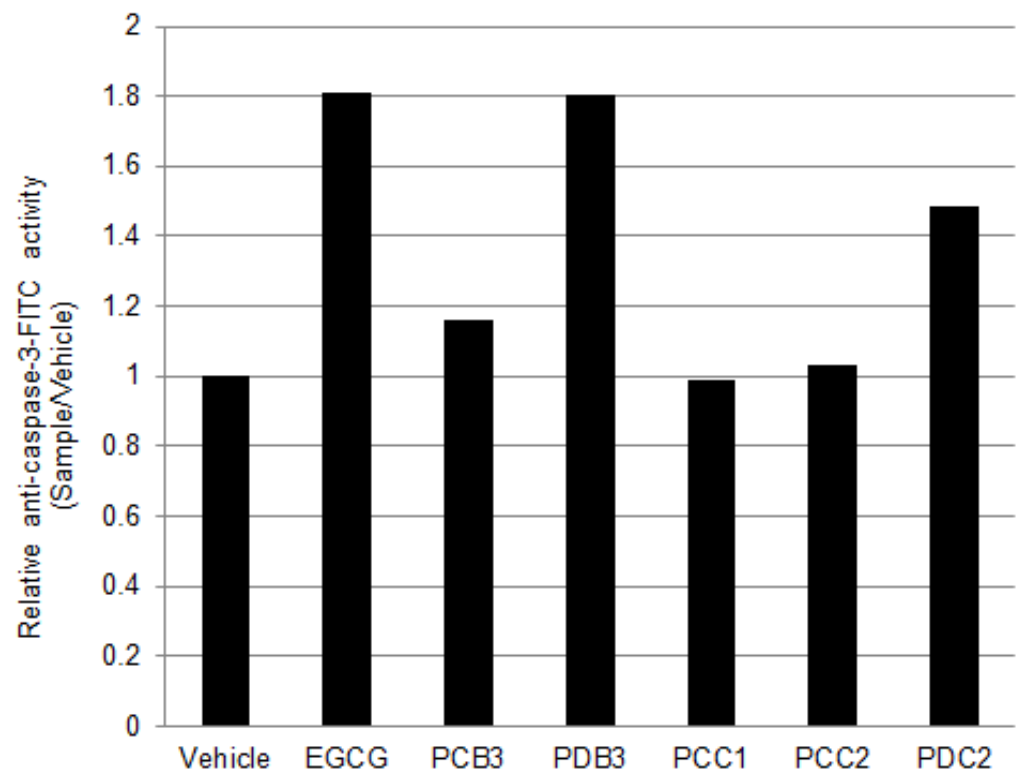

Figure 5. Effects of test compounds on caspase-3 activities assessed by FACS.

Assay for caspase-3 activities after treatment with test compounds $(5 \mu \mathrm{mol} / \mathrm{L}$ of CPT and $50 \mu \mathrm{mol} / \mathrm{L}$ of EGCG, PCB3, PDB3, PCC1, PCC2, or PDC2) were performed. The values represented are the rate of induction of apoptosis compared to the untreated control (vehicle). Experimental data are shown in the supplementary data.

\section{Conclusion}

The first total synthesis of prodelphinidin B3 (1) and C2 (2) have been achieved via Lewis acid-mediated equimolar condensation of a catechin and/or catechin-gallocatechin nucleophile with gallocatechin electrophiles. In addition to demonstrating the total synthesis, we examined their antitumor activities against PC-3 prostate cancer cells. We found that cytotoxic effects are clearly associated with the presence of the pyrogallol moiety of the $\mathrm{B}$ ring; procyanidins which lacked the pyrogallol moiety of the B ring did not show any potency. This activity of prodelphinidins might be ascribed to their blocking cell cycle partly at the G1/G0 phase and activating caspase-3. Prodelphinidins might be potential chemopreventing agents for prostate cancer cells. Based on this study's promising results, we are currently synthesizing various proanthocyanidins which contain pyrogallol moieties to clarify the mechanism of antitumor activity.

\section{Experimental}

4.1. General. All melting points were uncorrected. ${ }^{1} \mathrm{H}(500 \mathrm{MHz})$ and ${ }^{13} \mathrm{C}$ NMR $(125 \mathrm{MHz})$ spectra were measured with a Bruker DRX 500 FT-NMR spectrometer in $\mathrm{CDCl}_{3}$ or $\mathrm{CD}_{3} \mathrm{OD}$ with residual tetramethylsilane as the standard. The coupling constants were given in Hz. Mass spectra were obtained on JEOL JMS-SX102A and Waters Xevo QTOF mass spectrometers. IR spectra were recorded with JASCO FT-IR 480 Plus infrared spectrometer. Optical rotations were determined with a JASCO DIP-1000 polarimeter. 
4.1.1. $(2 R, 3 S, 4 S)$-3-Acetoxy-4-methoxy-5,7-3',4',5'-pentabenzyloxyflavan (6). To a solution of 5 (208 mg, $0.280 \mathrm{mmol})$ in $\mathrm{MeOH} / \mathrm{CH}_{2} \mathrm{Cl}_{2}(1 / 8,2.0 \mathrm{~mL})$ was added DDQ (250 $\left.\mathrm{mg}, 1.10 \mathrm{mmol}\right)$ at room temperature. After the resulting mixture had been stirred for $1 \mathrm{~h}$ at room temperature, the mixture was cooled to $0^{\circ} \mathrm{C}$ and the reaction was quenched with water. The mixture was extracted with $\mathrm{Et}_{2} \mathrm{O}(3 \times 20 \mathrm{~mL})$ and the combined organic layer was washed with brine, dried over $\mathrm{MgSO}_{4}$, filtered, and concentrated. The crude product was purified with silica gel column chromatography (hexane:AcOEt: $\mathrm{CH}_{2} \mathrm{Cl}_{2}=6: 1: 3$ ) to afford colorless solid. Acetylation of this compound using general procedure gave 6 (84 mg, 37\%, 2 steps) as a colorless oil. $[\alpha]_{\mathrm{D}}^{23}+32.4\left(\right.$ c 1.15, $\left.\mathrm{CHCl}_{3}\right)$; IR (film) $v_{\max } \mathrm{cm}^{-1}: 3088,3063,3032,2931,2829,1742,1616,1593,1230,1151,1108,736,696 ;{ }^{1} \mathrm{H}$ NMR $\left(\mathrm{CDCl}_{3},\right) \delta$ : 7.43-7.21 (25H, m), $6.81(2 \mathrm{H}, \mathrm{s}), 6.28(1 \mathrm{H}, \mathrm{d}, J=2.5 \mathrm{~Hz}), 6.18(1 \mathrm{H}, \mathrm{d}, J=2.0 \mathrm{~Hz}), 5.28-5.22(2 \mathrm{H}, \mathrm{m}), 5.15-4.97$ $(10 \mathrm{H}, \mathrm{m}), 4.77(1 \mathrm{H}, \mathrm{d}, J=2.5 \mathrm{~Hz}), 3.45(3 \mathrm{H}, \mathrm{s}), 1.77(3 \mathrm{H}, \mathrm{s}) ;{ }^{13} \mathrm{C} \mathrm{NMR}\left(\mathrm{CDCl}_{3}\right) \delta: 169.4,160.9,158.4,155.5$, $152.5,138.4,137.7,137.0,136.9,136.4,136.3,132.7,128.5,128.4,128.1,128.0,127.8,127.7,127.6,127.4$, 107.3, 103.1, 94.2, 93.7, 75.0, 74.5, 72.5, 71.3, 71.1, 70.4, 70.0, 69.4, 69.1, 59.0, 20.7; HRFABMS (M+Na) Calcd. for $\mathrm{C}_{53} \mathrm{H}_{48} \mathrm{NaO}_{9}, 851.3196$, Found; 851.3201.

4.1.2. $(2 R, 3 S, 4 S)$-3-Acetoxy-4-ethoxyethoxy-5,7,3',4',5'-pentabenzyloxyflavan (7). To a solution of 5 (118 $\mathrm{mg}, 0.160 \mathrm{mmol})$ in 2-ethoxyethanol/ $\mathrm{CH}_{2} \mathrm{Cl}_{2}(1 / 8,2.7 \mathrm{~mL})$ was added DDQ (106 $\left.\mathrm{mg}, 0.470 \mathrm{mmol}\right)$ at room temperature. After the resulting mixture had been stirred for $1 \mathrm{~h}$ at room temperature, the mixture was cooled to $0^{\circ} \mathrm{C}$ and the reaction was quenched with water. The mixture was extracted with $\mathrm{Et}_{2} \mathrm{O}(3 \times 10 \mathrm{~mL})$ and the combined organic layer was washed with brine, dried over $\mathrm{MgSO}_{4}$, filtered, and concentrated. The crude product was purified with silica gel column chromatography (hexane:AcOEt: $\mathrm{CH}_{2} \mathrm{Cl}_{2}=6: 1: 3$ ) to afford colourless solid. Acetylation of this compound using general procedure gave 7 (70 mg, 51\%, 2 steps) as a colorless oil. $[\alpha]_{\mathrm{D}}^{23}+31$ (c 1.9, $\mathrm{CHCl}_{3}$ ); IR (film) $v_{\max } \mathrm{cm}^{-1}: 3032,2925,1741,1616,1592,1230,1151,1110,736,697 ;{ }^{1} \mathrm{H} \mathrm{NMR}$ $\left(\mathrm{CDCl}_{3},\right) \delta: 7.48-7.20(25 \mathrm{H}, \mathrm{m}), 6.77(2 \mathrm{H}, \mathrm{d}, J=1.5 \mathrm{~Hz}), 6.26(1 \mathrm{H}, \mathrm{d}, J=2.0 \mathrm{~Hz}), 6.16(1 \mathrm{H}, \mathrm{d}, J=1.5 \mathrm{~Hz}), 5.28-$ $4.95(12 \mathrm{H}, \mathrm{m}), 4.88(1 \mathrm{H}, \mathrm{d}, J=3.0 \mathrm{~Hz}), 3.82-3.70(2 \mathrm{H}, \mathrm{m}), 3.50-3.40(4 \mathrm{H}, \mathrm{m}), 1.79(3 \mathrm{H}, \mathrm{s}), 1.15(3 \mathrm{H}, \mathrm{t}, J=7.0$

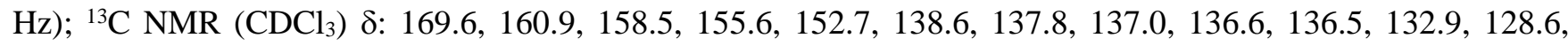
$128.5,128.4,128.1,128.0,127.8,127.7,127.6,127.5,107.6,103.6,94.3,93.8,75.1,74.5,72.6,71.2,70.7,70.5$, 70.3, 70.1, 68.2, 66.4, 20.7, 15.2; HRFABMS (M+Na) ${ }^{+}$: Calcd. for $\mathrm{C}_{56} \mathrm{H}_{54} \mathrm{NaO}_{10}, 909.3615$, Found; 909.3610.

\subsection{3. $[4,8$ ']-2,3-trans-3.4-trans:2',3'-trans-3-Acetoxy-nonabenzyloxy-(+)-gallocatechin-(+)-catechin (9). To} a solution of nucleophile 8 ( $28 \mathrm{mg}, 43 \mu \mathrm{mol})$ and electrophile 7 (38 mg, $43 \mu \mathrm{mol})$ in $\mathrm{CH}_{2} \mathrm{Cl}_{2}(4.0 \mathrm{~mL})$ was added $\mathrm{Yb}(\mathrm{OTf})_{3}(27 \mathrm{mg}, 43 \mu \mathrm{mol})$. After the resulting mixture had been stirred for $3 \mathrm{~h}$ at room temperature, the reaction was quenched with water. The mixture was extracted with EtOAc $(2 \times 10 \mathrm{~mL})$ and the combined organic layer was washed with brine, dried over $\mathrm{MgSO}_{4}$, filtered, and concentrated. The crude product was purified with preparative TLC (hexane:AcOEt: $\left.\mathrm{CH}_{2} \mathrm{Cl}_{2}=6: 1: 3\right)$ to afford $9(53 \mathrm{mg}, 86 \%)$ as pale yellow oil. $[\alpha]_{\mathrm{D}}{ }^{20}-114(c$ 
1.15, $\mathrm{CHCl}_{3}$ ); IR (film) $v_{\max } \mathrm{cm}^{-1}: 3524,3062,3031,2928,2870,1741,1593,1231,1114,735,696 ;{ }^{1} \mathrm{H} \mathrm{NMR}$ $\left(\mathrm{CDCl}_{3}, 1: 1\right.$ rotational isomer, major isomer) $\delta: 7.48-7.10(43.5 \mathrm{H}, \mathrm{m}), 6.94-6.60(7 \mathrm{H}, \mathrm{m}), 6.43(0.5 \mathrm{H}, \mathrm{dd}, J=8.5$, $1.5 \mathrm{~Hz}), 6.24(1 \mathrm{H}, \mathrm{s}), 6.22(0.5 \mathrm{H}, \mathrm{d}, J=2.0 \mathrm{~Hz}), 6.19(0.5 \mathrm{H}, \mathrm{d}, J=2.0 \mathrm{~Hz}), 6.15(0.5 \mathrm{H}, \mathrm{d}, J=2.0 \mathrm{~Hz}), 6.13(0.5 \mathrm{H}$, $\mathrm{d}, J=2.0 \mathrm{~Hz}), 5.98(0.5 \mathrm{H}, \mathrm{t}, J=9.5 \mathrm{~Hz}), 5.96(0.5 \mathrm{H}, \mathrm{s}), 5.85(0.5 \mathrm{H}, \mathrm{t}, J=9.5 \mathrm{~Hz}), 5.22-4.50(18.5 \mathrm{H}, \mathrm{m}), 3.84$ $(0.5 \mathrm{H}, \mathrm{m}), 3.56(0.5 \mathrm{H}, \mathrm{m}), 3.27(0.5 \mathrm{H}, \mathrm{d}, J=9.0 \mathrm{~Hz}), 3.01(0.5 \mathrm{H}, \mathrm{dd}, J=16.5,6.0 \mathrm{~Hz}), 2.86(1 \mathrm{H}, \mathrm{dd}, J=16.5$, $5.5 \mathrm{~Hz}), 2.72(0.5 \mathrm{H}, \mathrm{dd}, J=16.5,7.5 \mathrm{~Hz}), 2.35(0.5 \mathrm{H}, \mathrm{dd}, J=16.5,9.8 \mathrm{~Hz}), 2.05(0.5 \mathrm{H}, \mathrm{m}), 1.58(1.5 \mathrm{H}, \mathrm{s}), 1.49$ $(1.5 \mathrm{H}, \mathrm{s}), 1.27(0.5 \mathrm{H}, \mathrm{d}, J=1.5 \mathrm{~Hz}) ;{ }^{13} \mathrm{C} \mathrm{NMR}\left(\mathrm{CDCl}_{3}\right) \delta: 169.3,168.8,158.2,157.8,156.8,156.5,155.8,155.6$, $154.9,153.5,152.6,149.2,148.9,148.7,148.6$, 138.4, 138.2, 137.9, 137.8, 137.4, 137.3, 137.2, 137.1, 137.0, $136.9,136.8,136.5,133.0,132.7,132.6,132.3,128.3,128.1,128.0,127.9,127.8,127.7,127.6,127.5,127.4$, $127.3,127.2,127.1,126.9,126.8,120.3,120.0,114.8,114.6,114.2,113.3,110.6,110.5,110.0,108.5,108.2$, 107.9, 107.7, 107.2, 107.0, 102.4, 102.3, 94.8, 94.7, 94.5, 94.4, 91.1, 81.3, 80.7, 80.2, 76.7, 72.8, 72.1, 71.5, 71.3, 71.2, 71.1, 71.0, 70.9, 70.5, 70.4, 70.1, 70.0, 69.9, 69.8, 68.3, 67.9, 35.3, 35.1, 28.6, 26.7, 20.6, 20.4; HRFABMS $(\mathrm{M}+\mathrm{Na})^{+}$: Calcd. for $\mathrm{C}_{95} \mathrm{H}_{82} \mathrm{NaO}_{14}, 1469.5602$, Found; 1469.5597.

4.1.4. [4,8']-2,3-trans-3.4-trans:2',3'-trans-Nonabenzyloxy-(+)-gallocatechin-(+)-catechin (10). To a solution of $9(44 \mathrm{mg}, 30 \mu \mathrm{mol})$ in THF $(3.0 \mathrm{~mL})$ was added $40 \%$ aqueous $n$-Bu $4 \mathrm{NOH}(0.59 \mathrm{~mL}, 0.91 \mathrm{mmol})$. The reaction mixture was allowed to be stirred for $72 \mathrm{~h}$ at room temperature, then partially evaporated to remove THF. The residue was diluted with $\mathrm{H}_{2} \mathrm{O}(5.0 \mathrm{~mL})$, and the product was extracted with EtOAc $(2 \times 5.0 \mathrm{~mL})$. The combined organic layers were washed with brine and concentrated. The residue was purified with preparative TLC (hexane:AcOEt: $\left.\mathrm{CH}_{2} \mathrm{Cl}_{2}=4: 1: 2\right)$ to afford $10(35 \mathrm{mg}, 82 \%)$ as pale yellow oil. $[\alpha]_{\mathrm{D}}{ }^{19}-106\left(c 1.60, \mathrm{CHCl}_{3}\right)$; IR (film) $v_{\max } \mathrm{cm}^{-1}: 3566,3062,3031,2926,1592,1112,736,696 ;{ }^{1} \mathrm{H} \mathrm{NMR}\left(\mathrm{CDCl}_{3}, 2: 1\right.$ rotational isomer, major isomer) $\delta: ~ 7.47-7.20(40 \mathrm{H}, \mathrm{m}), 6.94-6.84(7 \mathrm{H}, \mathrm{m}), 6.94(1 \mathrm{H}, \mathrm{d}, J=2.0 \mathrm{~Hz}), 6.80(1 \mathrm{H}, \mathrm{dd}, J=8.5,2.0 \mathrm{~Hz}), 6.26$ $(1 \mathrm{H}, \mathrm{s}), 6.18(1 \mathrm{H}, \mathrm{d}, J=2.0 \mathrm{~Hz}), 6.13(1 \mathrm{H}, \mathrm{d}, J=2.0 \mathrm{~Hz}), 5.20-4.60(18 \mathrm{H}, \mathrm{m}), 4.57(2 \mathrm{H}, \mathrm{d}, J=11.0 \mathrm{~Hz}), 4.48$ $(1 \mathrm{H}, \mathrm{d}, J=9.5 \mathrm{~Hz}), 4.21(1 \mathrm{H}, \mathrm{dd}, J=9.5,8.5 \mathrm{~Hz}), 3.75-3.60(1 \mathrm{H}, \mathrm{m}), 3.59(1 \mathrm{H}, \mathrm{d}, J=8.0 \mathrm{~Hz}), 3.02(1 \mathrm{H}, \mathrm{dd}, J=$ 16.5, $5.8 \mathrm{~Hz}), 2.39(1 \mathrm{H}, \mathrm{dd}, J=16.0,9.0 \mathrm{~Hz}), 1.60-1.28(2 \mathrm{H}, \mathrm{m})$; minor isomer: $8: 7.47-7.27(20 \mathrm{H}, \mathrm{m}), 7.16-7.12$ $(3.5 \mathrm{H}, \mathrm{m}), 6.56(0.5 \mathrm{H}, \mathrm{d}, J=2.0 \mathrm{~Hz}), 6.48(0.5 \mathrm{H}, \mathrm{dd}, J=8.5,2.0 \mathrm{~Hz}), 6.35(0.5 \mathrm{H}, \mathrm{s}), 6.09(0.5 \mathrm{H}, \mathrm{d}, J=2.0 \mathrm{~Hz})$, $6.05(0.5 \mathrm{H}, \mathrm{d}, J=2.0 \mathrm{~Hz}), 5.16-4.65(10 \mathrm{H}, \mathrm{m}), 4.50(0.5 \mathrm{H}, \mathrm{d}, J=9.5 \mathrm{~Hz}), 4.45(0.5 \mathrm{H}, \mathrm{dd}, J=9.5,8.5 \mathrm{~Hz}), 4.18$ $(0.5 \mathrm{H}, \mathrm{d}, J=8.5 \mathrm{~Hz}), 3.75-3.60(0.5 \mathrm{H}, \mathrm{m}), 3.16(0.5 \mathrm{H}, \mathrm{dd}, J=16.5,6.0 \mathrm{~Hz}), 2.64(0.5 \mathrm{H}, \mathrm{dd}, J=16.5,9.0 \mathrm{~Hz})$, 1.70-1.35 (1H, m); ${ }^{13} \mathrm{C} \mathrm{NMR}\left(\mathrm{CDCl}_{3}\right) \delta: 158.0,157.8,157.6,156.7,155.6,155.5,154.0,152.9,152.8,149.1$, 149.0, 138.7, 137.9, 137.3, 137.2, 137.1, 137.0, 136.7, 134.2, 131.6, 130.6, 128.6, 128.5, 128.4, 128.3, 128.2, $128.1,127.9,127.8,127.7,127.6,127.5,127.4,127.2$, 127.1, 120.7, 120.2, 114.9, 114.3, 113.9, 112.0, 107.2, 106.9, 103.3, 102.6, 94.9, 91.9, 91.5, 82.3, 82.1, 81.3, 80.7, 77.6, 75.2, 73.4, 73.2, 71.3, 71.0, 70.3, 70.1, 70.0, 69.9, 68.6, 68.4, 37.2, 33.7, 31.9; HRFABMS (M+Na)': Calcd. for $\mathrm{C}_{93} \mathrm{H}_{80} \mathrm{NaO}_{13}, 1427.5497$, Found; 1427.5493.

4.1.5. Prodelphinidin B3 (1). A solution of $10(32 \mathrm{mg}, 23 \mu \mathrm{mol})$ in $\mathrm{THF} / \mathrm{MeOH} / \mathrm{H}_{2} \mathrm{O}(20 / 20 / 1)(4.0 \mathrm{~mL})$ was hydrogenated over $20 \% \mathrm{Pd}(\mathrm{OH})_{2} / \mathrm{C}(28 \mathrm{mg})$ for $3 \mathrm{~h}$ at room temperature. The mixture was filtered and the 
filtration residue was washed with $\mathrm{MeOH}(10 \mathrm{~mL})$. The combined filtrates were evaporated, and the residue was taken up in distilled water $(5.0 \mathrm{~mL})$. The solution was filtered and lyophilized to give $\mathbf{1}(13 \mathrm{mg}, 96 \%)$ as a fluffy amorphous solid. Mp 212-213 ${ }^{\circ} \mathrm{C}$ (decomp.); $[\alpha]_{\mathrm{D}}{ }^{19}-207$ (c 0.350, MeOH); IR (KBr) $v_{\max } \mathrm{cm}^{-1}: 3350,2924$, $1614,1520,1452,1365,1283,1233,1144,1032,821,628 ;{ }^{1} \mathrm{H}$ NMR $\left(\mathrm{CD}_{3} \mathrm{OD}, 2: 1\right.$ rotational isomer $) \delta: 6.94-$ $6.05(5 \mathrm{H}, \mathrm{m}), 5.88(0.67 \mathrm{H}, \mathrm{d}, J=2.0 \mathrm{~Hz}), 5.82(0.33 \mathrm{H}, \mathrm{d}, J=2.0 \mathrm{~Hz}), 5.82(0.33 \mathrm{H}, \mathrm{d}, J=2.5 \mathrm{~Hz}), 5.74(0.67 \mathrm{H}, \mathrm{d}$, $J=2.5 \mathrm{~Hz}), 4.73(0.33 \mathrm{H}, \mathrm{d}, J=7.0 \mathrm{~Hz}), 4.65(0.67 \mathrm{H}, \mathrm{d}, J=7.0 \mathrm{~Hz}), 4.48(1 \mathrm{H}, \mathrm{dd}, J=9.5,8.5 \mathrm{~Hz}), 4.42(1 \mathrm{H}, \mathrm{d}, J$ $=8.0 \mathrm{~Hz}), 4.34(0.67 \mathrm{H}, \mathrm{dd}, J=10.0,8.0 \mathrm{~Hz}), 4.28(0.33 \mathrm{H}, \mathrm{dd}, J=10.0,8.0 \mathrm{~Hz}), 4.23(0.67 \mathrm{H}, \mathrm{d}, J=9.5 \mathrm{~Hz}), 4.17$ $(0.33 \mathrm{H}, \mathrm{d}, J=9.0 \mathrm{~Hz}), 4.07(0.33 \mathrm{H}, \mathrm{m}), 3.78(0.67 \mathrm{H}, \mathrm{m}), 2.68(0.67 \mathrm{H}, \mathrm{dd}, J=16.0,5.0 \mathrm{~Hz}), 2.80(0.33 \mathrm{H}, \mathrm{dd}, J=$ 16.0, 5.0 Hz), $2.58(0.33 \mathrm{H}, \mathrm{dd}, J=16.0,7.8 \mathrm{~Hz}), 2.48(0.67 \mathrm{H}, \mathrm{dd}, J=16.5,8.0 \mathrm{~Hz}) ;{ }^{13} \mathrm{C} \mathrm{NMR}\left(\mathrm{CD}_{3} \mathrm{OD}\right) \delta: 158.7$, 157.2, 155.9, 155.8, 146.7, 146.6, 146.2, 145.6, 131.9, 131.7, 119.5, 116.3, 116.1, 115.1, 108.3, 107.9, 107.1, 101.7, 97.4, 96.9, 95.9, 84.3, 82.9, 82.0, 73.5, 68.6, 38.7, 38.5, 27.9; HRFABMS $(\mathrm{M}+\mathrm{Na})^{+}$: Calcd. for $\mathrm{C}_{30} \mathrm{H}_{26} \mathrm{NaO}_{13}, 617.1271$, Found; 617.1276.

4.1.6. Peracetate of 1 (11). A mixture of pyridine $(50 \mu \mathrm{L})$, acetic anhydride $(50 \mu \mathrm{L})$, and DMAP $(1.0 \mathrm{mg})$ was added to 1 ( $4.0 \mathrm{mg}, 6.7 \mu \mathrm{mol})$. After the reaction mixture had been stirred for $12 \mathrm{~h}$, saturated aqueous $\mathrm{NaHCO}_{3}(5$ $\mathrm{mL})$ was added, and the product was extracted with EtOAc $(2 \times 10 \mathrm{~mL})$. The organic layers were washed with $\mathrm{H}_{2} \mathrm{O}(5.0 \mathrm{~mL})$ and brine, and dried over $\mathrm{MgSO}_{4}$, filtered, and concentrated. The crude product was purified with preparative TLC (hexane:AcOEt: $\left.\mathrm{CH}_{2} \mathrm{Cl}_{2}=6: 1: 3\right)$ to afford peracetate $\mathbf{1 1}(2.0 \mathrm{mg}, 28 \%$ ) as colorless glass. IR (film) $v_{\max } \mathrm{cm}^{-1}: 2924,2851,1772,1617,1505,1431,1371,1206,1127,1046,896,736 ;{ }^{1} \mathrm{H} \mathrm{NMR}\left(\mathrm{CDCl}_{3}\right) \delta$ : $7.12(1 \mathrm{H}, \mathrm{d}, J=8.5 \mathrm{~Hz}), 6.96(2 \mathrm{H}, \mathrm{s}), 6.90(1 \mathrm{H}, \mathrm{d}, J=2.0 \mathrm{~Hz}), 6.70(1 \mathrm{H}, \mathrm{dd}, J=8.5,2.0 \mathrm{~Hz}), 6.65(1 \mathrm{H}, \mathrm{s}), 6.49$ $(2 \mathrm{H}, \mathrm{s}), 5.61(1 \mathrm{H}, \mathrm{dd}, J=10.0,8.0 \mathrm{~Hz}), 5.08-4.99(2 \mathrm{H}, \mathrm{m}), 4.71(1 \mathrm{H}, \mathrm{d}, J=10.0 \mathrm{~Hz}), 4.50(1 \mathrm{H}, \mathrm{d}, J=9.5 \mathrm{~Hz})$, $2.86(1 \mathrm{H}, \mathrm{m}), 2.66(1 \mathrm{H}, \mathrm{m}), 2.35(3 \mathrm{H}, \mathrm{s}), 2.29-2.24(21 \mathrm{H}, \mathrm{m}), 1.98(3 \mathrm{H}, \mathrm{s}), 1.95(3 \mathrm{H}, \mathrm{s}), 1.70(3 \mathrm{H}, \mathrm{s}) ;{ }^{13} \mathrm{C}$ NMR $\left(\mathrm{CDCl}_{3}\right) \delta: 170.1,169.1,168.6,168.4,168.1,167.7,167.5,166.6,155.8,152.6,149.6,149.2,149.0,147.9,147.6$, $143.3,143.2,142.0,141.6,135.2,135.0,134.7,134.6,124.5,123.4,122.2,121.7,120.0,119.6,116.7,115.2$, 111.3, 110.2, 110.0, 109.6, 109.4, 108.2, 107.9, 78.8, 77.9, 77.7, 70.4, 68.3, 68.1, 36.7, 29.7, 25.2, 21.1, 20.9, 20.7, 20.6, 20.4, 20.3, 20.1.

\subsection{7. [4,8:4",8"]-2,3-trans-3,4-trans: 2",3"-trans-3",4"-trans:2",,3",-trans-Acetoxytetradecabenzyloxy-(+)-} gallocatechin-(+)-gallocatechin-(+)-catechin (12). To a solution of nucleophile $\mathbf{1 0}(43 \mathrm{mg}, 31 \mu \mathrm{mol})$ and electrophile 6 (26 mg, $31 \mu \mathrm{mol})$ in $\mathrm{CH}_{2} \mathrm{Cl}_{2}(4.0 \mathrm{~mL})$ under an argon atmosphere was added $\mathrm{AgOTf}(7.8 \mathrm{mg}, 31$ $\mu \mathrm{mol})$. After the resulting mixture had been stirred for $5 \mathrm{~h}$ at room temperature, the reaction was quenched with water. The mixture was extracted with AcOEt, and the combined organic layer was washed with brine, dried over $\mathrm{MgSO}_{4}$, filtered, and concentrated. The crude product was purified with silica gel column chromatography (hexane:AcOEt: $\left.\mathrm{CH}_{2} \mathrm{Cl}_{2}=6: 1: 3\right)$ to give $12(49 \mathrm{mg}, 73 \%)$ as an pale yellow oil. $[\alpha]_{\mathrm{D}}{ }^{19}-80\left(c 0.23, \mathrm{CHCl}_{3}\right)$; IR (film) $v_{\max } \mathrm{cm}^{-1}: 3566,3062,3031,2927,2829,1741,1593,1113,735,696$; HRFABMS (M+Na)+: Calcd. for 
$\mathrm{C}_{145} \mathrm{H}_{124} \mathrm{NaO}_{21}, 2223.8533$, Found; 2223.8521.

4.1.8. [4,8:4",8"]-2,3-trans-3,4-trans: 2",3"-trans-3",4"-trans:2",,3",-trans-Tetradecabenzyloxy-(+)gallocatechin-(+)-gallocatechin-(+)-catechin (13). To a solution of 12 (60 mg, $0.025 \mathrm{mmol})$ in THF (3.0 mL) was added $n-\mathrm{Bu}_{4} \mathrm{NOH}(0.46 \mathrm{~mL}, 0.76 \mathrm{mmol})$. The reaction mixture was allowed to be stirred for $72 \mathrm{~h}$ at room temperature, then partially evaporated to remove THF. The residue was diluted with $\mathrm{H}_{2} \mathrm{O}(5.0 \mathrm{~mL})$, and the product was extracted with EtOAc $(2 \times 5.0 \mathrm{~mL})$. The combined organic layers were washed with brine and concentrated. The residue was purified with preparative TLC (hexane:AcOEt: $\mathrm{CH}_{2} \mathrm{Cl}_{2}=6: 1: 3$ ) to afford 13 (44 $\mathrm{mg}, 77 \%)$ as an pale yellow oil. $[\alpha]_{\mathrm{D}}^{22}-91$ ( $\left.c 0.14, \mathrm{CHCl}_{3}\right)$; IR (film) $v_{\max } \mathrm{cm}^{-1}: 3573,3062,3031,2869,1742$, 1593, 1113, 735, 696; ${ }^{1} \mathrm{H} \mathrm{NMR}\left(\mathrm{CDCl}_{3}, 0.82: 0.18\right.$ mixture of rotational isomer, major isomer $) \delta=7.44-5.90$ $(81 \mathrm{H}, \mathrm{m}), 5.57-4.40(30 \mathrm{H}, \mathrm{m}), 4.25(1 \mathrm{H}, \mathrm{d}, J=8.8 \mathrm{~Hz}), 4.05-3.95(2 \mathrm{H}, \mathrm{m}), 3.81-3.75(1 \mathrm{H}, \mathrm{m}), 3.57(1 \mathrm{H}, \mathrm{d}, J=$ $9.0 \mathrm{~Hz}), 3.10(1 \mathrm{H}, \mathrm{dd}, J=16.0,6.0 \mathrm{~Hz}), 2.92(1 \mathrm{H}, \mathrm{d}, J=9.5 \mathrm{~Hz}), 2.37(1 \mathrm{H}, \mathrm{dd}, J=16.5,9.8 \mathrm{~Hz}), 1.52(2 \mathrm{H}$, brs, $\mathrm{OH}), 1.12(1 \mathrm{H}$, brs, $-\mathrm{OH}) ;{ }^{13} \mathrm{C} \mathrm{NMR}\left(\mathrm{CDCl}_{3}\right)$ 8: 158.0, 157.9, 156.6, 156.5, 156.0, 155.6, 155.5, 155.3, 155.2, 155.0, 153.9, 152.9, 152.7, 152.5, 149.4, 149.1, 138.4, 138.3, 138.1, 138.0, 137.8, 137.4, 137.2, 137.1, 136.0, $134.7,134.6,128.9,128.5,128.4,128.3,128.2$, 128.1, 127.9, 127.8, 127.7, 127.6, 127.5, 127.4, 127.3, 127.2, 127.1, 127.0, 120.7, 115.2, 114.6, 112.5, 109.5, 108.9, 108.0, 107.5, 107.1, 107.0, 102.6, 94.9, 94.1, 92.2, 91.9, 82.2, 81.1, 75.2, 75.0, 73.0, 72.9, 71.4, 71.3, 71.1, 70.6, 70.4, 70.3, 70.0, 69.9, 68.4, 37.7, 37.4, 29.7; HRFABMS $(\mathrm{M}+\mathrm{Na})^{+}$: Calcd. for $\mathrm{C}_{143} \mathrm{H}_{122} \mathrm{NaO}_{20}, 2181.8427$, Found; 2181.8440 .

4.1.9. Prodelphinidin C2 (2). A solution of $13(32 \mathrm{mg}, 15 \mu \mathrm{mol})$ in $\mathrm{THF} / \mathrm{MeOH} / \mathrm{H}_{2} \mathrm{O}(20 / 20 / 1)(4.0 \mathrm{~mL}) \mathrm{was}$ hydrogenated over $20 \% \mathrm{Pd}(\mathrm{OH})_{2} / \mathrm{C}(28 \mathrm{mg})$ for $3 \mathrm{~h}$ at room temperature. The mixture was filtered and the filtration residue was washed with $\mathrm{MeOH}(10 \mathrm{~mL})$. The combined filtrates were evaporated, and the residue was taken up in distilled water $(5.0 \mathrm{~mL})$. The solution was filtered and lyophilized to give $2(13 \mathrm{mg}, 96 \%)$ as a fluffy amorphous solid. Mp 218-220 ${ }^{\circ} \mathrm{C}$ (decomp.); $[\alpha]_{\mathrm{D}}^{21}-283$ (c 0.350, MeOH); IR (KBr) $v_{\max } \mathrm{cm}^{-1}: 3350,2925$, $1616,1523,1453,1367,1281,1238,1140,1035,821,629 ;{ }^{1} \mathrm{H}$ NMR $\left(\mathrm{CD}_{3} \mathrm{OD}\right) \delta=7.05-5.75(11 \mathrm{H}, \mathrm{m}), 4.80-4.05$ $(6 \mathrm{H}, \mathrm{m}), 2.90-2.40(4 \mathrm{H}, \mathrm{m}) ;{ }^{13} \mathrm{C} \mathrm{NMR}\left(\mathrm{CD}_{3} \mathrm{OD}\right) \delta=158.6,157.7,157.2,155.9,155.8,155.6,155.5,155.4,155.3$, $155.2,155.1,155.0,146.7,146.2,146.0,145.9,134.2,130.8,124.5,120.2,117.6,116.2,115.3,108.7,108.5$, 108.3, 97.4, 96.1, 95.7, 84.0, 83.2, 81.9, 73.0, 69.8, 68.6, 68.5, 68.3, 38.9, 38.8, 30.8, 21.3; ESI-TOFMS calcd for $\mathrm{C}_{45} \mathrm{H}_{38} \mathrm{O}_{20} \mathrm{Na}(\mathrm{M}+\mathrm{Na})^{+}$; 921.1854 ; found 921.1941.

4.1.10. Peracetate of 2 (14). A mixture of pyridine $(50 \mu \mathrm{L})$, acetic anhydride $(50 \mu \mathrm{L})$, and DMAP $(1.0 \mathrm{mg})$ was added to $2(4.0 \mathrm{mg}, 4.5 \mu \mathrm{mol})$. After the reaction mixture had been stirred for $12 \mathrm{~h}$, saturated aqueous $\mathrm{NaHCO}_{3}$ $(5.0 \mathrm{~mL})$ was added, and the product was extracted with EtOAc $(2 \times 10 \mathrm{~mL})$. The organic layers were washed with $\mathrm{H}_{2} \mathrm{O}(5.0 \mathrm{~mL})$ and brine, and dried over $\mathrm{MgSO}_{4}$, filtered, and concentrated. The crude product was purified with preparative TLC (hexane:AcOEt: $\left.\mathrm{CH}_{2} \mathrm{Cl}_{2}=6: 1: 3\right)$ to afford peracetate $\mathbf{1 4}(2.0 \mathrm{mg}, 27 \%$ ) as colorless 
glass. IR (film) $v_{\max } \mathrm{cm}^{-1}: 2925,2850,1773,1619,1502,1433,1370,1207,1128,1042,896,736 ;{ }^{1} \mathrm{H}$ NMR $\left(\mathrm{CDCl}_{3}\right)$ 8: $7.05(1 \mathrm{H}, \mathrm{d}, J=8.5 \mathrm{~Hz}), 6.96(2 \mathrm{H}, \mathrm{s}), 6.86(1 \mathrm{H}, \mathrm{d}, J=2.0 \mathrm{~Hz}), 6.67(2 \mathrm{H}, \mathrm{s}), 6.64(1 \mathrm{H}, \mathrm{s}), 6.63(1 \mathrm{H}, \mathrm{d}$, $J=6.5 \mathrm{~Hz}), 6.54(1 \mathrm{H}, \mathrm{d}, J=2.5 \mathrm{~Hz}), 6.25(1 \mathrm{H}, \mathrm{d}, J=2.5 \mathrm{~Hz}), 5.57(1 \mathrm{H}, \mathrm{dd}, J=19.0,9.5 \mathrm{~Hz}), 5.47(1 \mathrm{H}, \mathrm{dd}, J=$ $19.0,9.5 \mathrm{~Hz}), 5.30-5.15(2 \mathrm{H}, \mathrm{m}), 4.78(1 \mathrm{H}, \mathrm{d}, J=10.0 \mathrm{~Hz}), 4.66(1 \mathrm{H}, \mathrm{d}, J=10.0 \mathrm{~Hz}), 4.58(1 \mathrm{H}, \mathrm{d}, J=8.0 \mathrm{~Hz})$, $4.18(1 \mathrm{H}, \mathrm{d}, J=9.0 \mathrm{~Hz}), 2.56(2 \mathrm{H}, \mathrm{s}), 2.38-1.61$ (OAc-groups).

\subsection{Biochemical methods}

4.2.1. Cell lines, cell culture and reagents. THuman prostate cancer cell, PC-3, was purchased from the Health Science Research Resources Bank. The cells were maintained in monolayer culture at $37^{\circ} \mathrm{C}$ and $5 \% \mathrm{CO}_{2}$ in RPMI-1640 (SIGMA, R8755) supplemented with 10\% charcoal-stripped fetal bovine serum (Biological Industries, No. 04-201-1), 1\% antibiotic-antimycotic mixed stock solution (Nacalai Tesque, No. 09366-44). The cells were treated with various concentrations of epigallocatechine-3-gallate (EGCG), procyanidin B3 (PCB3), procyanidin $\mathrm{C} 1$ ( $\mathrm{PCC} 1)$, procyanidin $\mathrm{C} 2$ ( $\mathrm{PCC} 2)$, prodelphinidin $\mathrm{B} 3$ (PDB3), prodelphinidin $\mathrm{C} 2$ (PDC2) or camptothecin (CPT) for 48 h. CPT (WAKO, No. 038-18191) was used for the index of apoptosis. EGCG was generously gifted from Prof. Dr. Toshiyuki Kan in University of Shizuoka.

4.2.2. Cell count (Figure 3 A). Cells were plated in 12 -well plates $\left(1 \times 10^{4}\right.$ cells/well) and grew to reach $50 \%$ confluent. The cells were treated with the indicated concentrations of EGCG, PCB3, PCC1, PCC2, PDB3, PDC2, or CPT for $48 \mathrm{~h}$. The cells treated with the above test compounds were trypsinized. After adding the culture medium to each well, they were agitated by pipetting. The number of cells was measured with the hemocytometer.

4.2.3. MTT (3-[4,5-dimethylthiazol-2-yl]-2,5-diphenyltetrazolium bromide) assay (Figure 3 B). The degree of cell proliferation was evaluated by MTT assay using Cell Count Kit (Nacalai Tesque, No. 23506-80), according to the manufacturer's protocol. The cells were plated in 96-well plates and treated with the indicated concentrations of EGCG, PCB3, PCC1, PCC2, PDB3, PDC2, or CPT for 48 h. Absorbance at 595 nm was measured using the microplate reader after the addition of the MTT solvent.

4.2.4. Measurement of apoptosis by assay for caspase-3 activity (Figure 5). Assay for caspase-3 activities were carried out using BD Cytofix/Cytoperm ${ }^{\mathrm{TM}}$ Kit (BD Biosciences, No. 554714), according to the manufacturer's protocol. Purified rabbit anti-active caspase-3 (BD Pharmingen ${ }^{\mathrm{TM}}$, No. 559565) was used for the first antibody ( $\left.1^{\text {st }} \mathrm{Ab}\right)$ and FITC-conjugate anti-rabbit Ig G (Jackson ImmunoResearch, No. 711-096-152) was used for the second antibody $\left(2^{\text {nd }} \mathrm{Ab}\right.$ ). Briefly, after treatment of cells with $50 \mu \mathrm{M}$ of EGCG, PCB3, PCC1, 
PCC2, PDB3, PDC2, or $500 \mathrm{nM}$ of CPT for $48 \mathrm{~h}$, the cells were collected and prepared by the same method as cell cycle analysis described in Materials and methods. The cells were diluted in PBS and fixed with BD Cytofix/Cytoperm ${ }^{\mathrm{TM}}$ Fixation and Permeabilization Solution for $20 \mathrm{~min}$ on ice in the dark. The cells were washed with the washing buffer and then reacted with $1^{\text {st }} \mathrm{Ab}$ at room temperature. Next, the cells were washed with the washing buffer and then reacted with $2^{\text {nd }} \mathrm{Ab}$ at room temperature. After the reaction, the cells were diluted in PBS, and flow cytometry was performed with a FACScan (Becton Dickinson, Japan), and the data obtained were analyzed utilizing Cell Quest software. For each sample, $1 \times 10^{4}$ cells were recorded.

4.2.5. Statistical analysis. Each experiment was performed at least three times. Data were expressed as the means \pm standard deviation (S. D.). Statistical analysis was performed using Student's t-test. $\mathrm{P}<0.05$ or $\mathrm{P}<0.01$ was considered to be significant.

\section{Acknowledgements}

This work was supported in part by Grant-in-Aid for Scientific Research from the Ministry of Education, Science, Culture, Sports, and Technology of Japan (22570112 to H. F.) and by Grant from Uehara Memorial Foundation (to H. F.). We also thank Prof. Dr. Toshiyuki Kan for providing EGCG and Mr. Hideyuki Karasawa at Nagano Prefecture General Industrial Technology Center for obtaining the ESI-TOF mass spectrum of prodelphinidin C2 (2).

\section{Supplementary data}

Supplementary data associated with this article can be found, in the online version, at http://dx.doi

\section{References and notes}

1. Ferreira, D.; Li, X. -C. Nat. Prod. Rep. 2000, 17, 193.

2. Ferreira, D.; Li, X. -C. Nat. Prod. Rep. 2002, 19, 517.

3. Ferreira, D.; Coleman, C. M. Planta Med. 2011, 77, 1071.

4. Oyama, K. -i.; Yoshida, K.; Kondo, T. Curr. Org. Chem. 2011, 15, 2567.

5. Ohmori, K.; Suzuki, K. Curr. Org. Chem. 2012, 16, 566.

6. Nakajima, N.; Horikawa, K.; Takekawa, N.; Hamada, M.; Kishimoto, T. Heterocycles 2012, 84, 349.

7. Katoh, M.; Oizumi, Y.; Mohri, Y.; Hirota, M.; Makabe, H. Lett. Org. Chem. 2012, 9, 233.

8. Alharthy, R. D.; Hayes, C. J. Tetrahedron Lett. 2010, 51, 1193. 
9. Oizumi, Y.; Mohri, Y.; Hirota, M.; Makabe, H. J. Org. Chem. 2010, 75, 4884.

10. Mohri, Y.; Sagehashi, M.; Yamada, T.; Hattori, Y.; Morimura, K.; Hamauzu, Y.; Kamo, T.; Hirota, M.; Makabe, H. Heterocycles 2009, 79, 549.

11. Oyama, K. -i.; Kuwano, M.; Ito, M.; Yoshida, K.; Kondo, T. Tetrahedron Lett. 2008, 49, 3176.

12. Viton, F.; Landreau, C.; Rustidge, D.; Robert, F.; Williamson, G.; Barron, G. Eur. J. Org. Chem. $2008,6069$.

13. Mohri, Y.; Sagehashi, M.; Yamada, T.; Hattori, Y.; Morimura, K.; Kamo, T.; Hirota, M.; Makabe, H. Tetrahedron Lett. 2007, 48, 5891.

14. Tarascou, I.; Barathieu, K.; André, Y.; Pianet, I.; Dufourc, E. J.; Fouquet, E. Eur. J. Org. Chem. 2006, 5367.

15. Sakuda, H.; Saito, A.; Mizushina, Y.; Yoshida, H.; Tanaka, A.; Nakajima, N. Heterocycles 2006, 67, 175.

16. Saito, A.; Mizushina, Y.; Ikawa, H.; Yoshida, H.; Doi, Y.; Tanaka, A.; Nakajima, N. Bioorg. Med. Chem. 2005, 13, 2759.

17. Saito, A.; Nakajima, N.; Matsuura, N.; Tanaka, A.; Ubukata, M. Heterocycles 2004, 62, 479.

18. Saito, A.; Nakajima, N.; Tanaka, A.; Ubukata, M. Heterocycles 2003, 61, 287.

19. Saito, A.; Nakajima, N.; Tanaka, A.; Ubukata, M. Tetraherdron 2002, 58, 7829.

20. Tückmantel, W.; Kozikowski, A. P.; Romanczyk, Jr. L. J. J. Am. Chem. Soc. 1999, 121, 12073.

21. Yano, T.; Ohmori, K.; Takahashi, H.; Kusumi, T.; Suzuki, K.; Org. Biomol. Chem. 2012, 10, 7685.

22. Oizumi, Y.; Katoh, M.; Hattori, Y.; Toda, K.; Kawaguchi, K.; Fujii, H.; Makabe, H. Heterocycles 2012 , 85, 2241.

23. Ohmori, K.; Ushimaru, N.; Suzuki, K. Proc. Natl. Acad. Sci. U. S. A. 2004, 101, 12002.

24. Saito, A.; Doi, Y.; Tanaka, A.; Matsuura, N.; Ubukata, M.; Nakajima, N. Bioorg. Med. Chem. 2004, 12, 4783.

25. Saito, A.; Tanaka, A.; Ubukata, M.; Nakajima, N. Synlett 2004, 1069.

26. Ohmori, K.; Shono, T.; Hatakoshi, Y.; Yano, T.; Suzuki, K.; Angew. Chem. Int. Ed. 2011, 50, 4862.

27. Saito, A.; Mizushina, Y.; Tanaka, A.; Nakajima, N. Tetrahedron 2009, 65, 7422.

28. Kozikowski, A. P.; Tückmantel, W.; Böttcher, G.; Romanczyk, Jr. L. J. J. Org. Chem. 2003, 68, 1641.

29. Krohn, K.; Ahmed, I.; John, M.; Letzel, M. C.; Kuck, D. Eur. J. Org. Chem. 2010, 2544. 
30. Oizumi, Y.; Mohri, Y.; Hattori, Y.; Makabe, H. Heterocycles 2011, 83,739.

31. Wan, S. B.; Dou, Q. P.; Chan, T. H. Tetrahedron 2006, 62, 5897.

32. Delcour, J. A.; Vercruysse, S. A. R. J. Inst. Brew. 1986, 92, 244.

33. We observed that interflavan bond (C8-C4) of the synthetic prodelphinidin B3 (2) was partially cleaved during acetylation. We isolated the peracetate of catechin and gallocatechin. This is the reason of the low yield of acetylation. The loe to moderate yields of actetylation of pure epicatechin ligomers were also reported in ref. 28.

34. HPLC measurement condition of prodelphinidin C2 (2): column; InertSustain C18 $250 \times 4.6$ mm Waters, eluent $0.1 \% \mathrm{HCOOH}-\mathrm{CH}_{3} \mathrm{CN}$, flow rate: $0.5 \mathrm{~mL} / \mathrm{min}$, detection: UV $280 \mathrm{~nm}$, retention time: $13.18 \mathrm{~min}$.

35. When we acetylated prodelphin C2 (2) to obtain peracetate 14, we isolated the peractate of dimer 11, catechin dimer, catechin, and gallocatechin. This is the reason of the low yield of acetylation of prodelphinidin C2 (2).

36. Mitsuhashi, S.; Saito, A.; Nakajima, N.; Shima, H.; Ubukata, M. Molecules 2008, 13, 2998.

37. Collins, J. A.; Schandi, C. A.; Young, K. K.; Vesely, J.; Willingham, M. C. J. Histochem. Cytochem. 1997, $45,923$.

38. Zi, X. L.; Agarwal, R. Proc. Natl. Acad. Sci. U.S.A. 1999, 96, 7490.

39. Kandasamy, K. ; Srinivasula, S. M.; Alnemri, E. S.; Thompson, C. B.; Korsmeyer, S. J.; Bryant, J. L.; Srivastana, R. K. Cancer Res. 2003, 63, 1712.

40. Goyal, L. Cell 2001, 104, 805. 


\section{Graphical Abstract}

\section{Synthesis of prodelphinidin B3 and C2, and their antitumor activity}

Wataru Fujii, Kazuya Toda, Koichiro Kawaguchi, Sei-ichi Kawahara, Miyuki Katoh, Yasunao Hattori, Hiroshi Fujii and Hidefumi Makabe

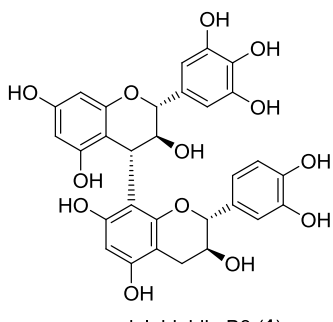

prodelphinidin B3 (1)

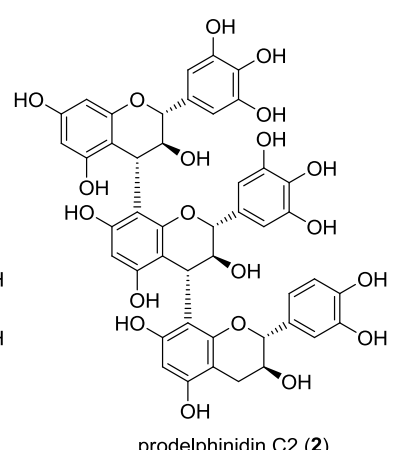

prodelphinidin C2 (2) 